\title{
Citizen Participation in Environmental Law Enforcement in Nicaragua: A Comparative Study of Nicaraguan, United States and German Environmental Law
}

\author{
By Martin Kellner, Freiburg (Breisgau)*
}

\section{Introduction}

Nicaragua possesses an elaborated environmental law to protect its natural resources and its beauty of nature. ${ }^{1}$ However, the implementation of the relevant statutes is imperfect in several respects. The reasons for this deficit are manifold. On the one hand, they can be found in a lack of financial resources of the governmental administration. On the other hand, in spite of Nicaragua's specific problems of a developing country, deficient implementation of environmental law is known in all legal systems. The reason for this tendency is that in environmental law with regard to the protection of nature the protection of a general benefit is in question, and often an omission of implementation does not injure any individual who could claim statutory enactment. ${ }^{2}$ However, many legal systems have developed mechanisms to overcome administrative inaction.

This article will discuss citizen participation as a remedy to the problem of administrative passivity. The General Environmental Law of Nicaragua (Ley General del Medio Ambiente y Los Recursos Naturales) ${ }^{3}$ provides that every citizen can initiate administrative or criminal proceedings against those who violate this law. With the citizen suit in the U.S. law and the association action (Verbandsklage) in German law similar forms of environmental enforcement were created. All these forms of citizen participation shall ensure that private parties have the possibility to enforce the law on behalf of the public at large.

Martin Kellner LL.M. (Vanderbilt), Dr. jur., research fellow at the Universities Frankfurt/M and Speyer until 2008; now judge in Baden-Württemberg. E-mail: martin_kellner@gmx.de. The author would like to express his gratitude to the Fritz Thyssen Foundation, Cologne, for supporting his research in Nicaragua.

1 Cf. María Fernanda Usubillaga Velásquez, Manual de Clase Derecho Ambiental en Nicaragua, p. 20-21 (Universidad Centroamericana 2005).

Martin Gellermann, Introduction to § 58 BNatSchG n. 1, in: Robert Landmann / Gustav Rohmer (eds.), Umweltrecht, vol. IV, 2005; Martin Kellner, Informal Cooperation as an Emerging Method of Administration and How It Is to Be Governed, Journal of Interdisciplinary Economics 19 (2008), 153, 155.

Ley No. 217 of 27.03.1996, available at <http://www.lexadin.nl> (accessed 15.07.2009); see also Pauni Obregón Ortega, Marco Jurídico de la Participación Ciudadana, Revista de Derecho Universidad Centroamericana 2 (2002), 34. 
The opening part of this article will present a short history of environmental law and citizen participation in Nicaragua (Part II). Furthermore, the article will discuss citizen participation against the backdrop of U.S. and German environmental law. Interestingly, in the legal systems of the U.S. and Germany converse tendencies in the scope of citizen participation can be noted: Whereas the U.S. Supreme Court suspended citizen suits as a form of citizen participation at the courts (discussed in Part III), the German legislature is expanding citizen participation (Part IV). The final part (Part V) discusses what lessons can be drawn from the U.S. and the German experiences with citizen participation.

\section{Environmental Law and Citizen Participation in Nicaragua}

In the 1990s Nicaragua - like other developing countries in Latin America and around the world - enacted comprehensive environmental protection legislation. ${ }^{4}$ Impulses for the legislation came from internal forces, but also major external factors.

\section{Internal and External Forces}

Internal reasons for the legislative activities can already be found in the Political Constitution of Nicaragua (Constitución Política de la República de Nicaragua) of 1987. ${ }^{5}$ This constitution stipulates in several Articles that the State has to protect the environment and the natural resources. In order to fulfill the constitutional requirements the legislature created - among others provisions - in 1996 the General Environmental Law of Nicaragua (Ley General del Medio Amiente y los Recursos Naturales). This statute established norms to conserve, improve and restore the environment and the natural resources. ${ }^{6}$

However, maybe the World Bank and the United Nations (UN) epitomize more powerfully external forces that urged the legislature to become active in the field of environmental protection. The World Bank continues to support the development of environmental regulatory programs in developing countries. Already since October 1989, the World Bank has required detailed consideration of the potential environmental impacts of World Bank supported projects. These include projects using funds provided at little or no interest to

David W. Tundermann, Chapter Emerging in Environmental Law in Latin America: Lessons Learned and Challenges Ahead, in: 43rd Annual Rocky Mountain Mineral Law Institute, 1997, § 10.01 .

Political Constitution of Nicaragua of 09.01.1987, available at Georgetown University, Political Database of the Americas <http://pdba.georgetown.edu> (accessed 15.07.2009); a German translation can be found in Jahrbuch des Öffentlichen Rechts der Gegenwart 37 (1988), 720-740.

6

See Mauro Xavier Ampié Vílchez, Manual de Derecho Constitucional, p. 226 (Universidad Centroamericana 2006); Iván Escobar Fornos, Los Derechos Humanos y su defensa, p. 342 (Hispamer 2003); Usubillaga Velásquez, note 1, p. 70-71. 
member countries for public projects, and funds loaned to industry for private project development. ${ }^{7}$ Indeed, the World Bank may be the single most influential force behind the progressive environmental laws and controls in Latin America and throughout the world. For example, as a condition to a country receiving loans or funds from the International Development Association (IDA), the World Bank requires the preparation of a national environmental plan which identifies the need for legal and institutional changes, such as the enactment of legislation, promulgating regulation, and strengthening regulatory agencies and programs aimed at protecting the environment. ${ }^{8}$ After the preparation of the National Environmental Action Plan, World Bank legal and technical personnel reviewed and commented on draft environmental legislation. ${ }^{9}$ Furthermore, the World Bank policies have encouraged and enhanced the participation of Non-governmental Organizations (NGOs) in the monitoring of environmental impacts of World-Bank-sponsored projects. ${ }^{10}$

Also the UN promotes a mutual understanding and cooperation in the global development of environmental controls. In 1972, the UN Conference on the Human Environment held in Stockholm, Sweden, resulted in the Stockholm Declaration. ${ }^{11}$ Principle 22 of the Declaration provides that "States shall cooperate to develop further the international law regarding liability and compensation for the victims of pollution and other environmental damage". The United Nations Environmental Program (UNEP), which grew out of the Stockholm Conference, included in its mission that it will assist member nations in the development of environmental assessment and environmental management programs. ${ }^{12}$ Later, UNEP expanded its technical, legal, and institutional assistance for the development of national environmental legislation. The UN program has prepared model legislation and guidelines for governments of developing countries, and conducted numerous environmental law training workshops for governmental personnel.

Furthermore, broad consensus for the need for international environmental management standards was recognized by the U.N. Conference on Environmental and Development -

Ian A. Bowles / Cyril F. Kormos, Environmental Reform at the World Bank, Virginia Journal of International Law 35 (1995), 777, 825-828.

8 Tundermann, note 4, p. § 10.02 [1].

9 Cf. World Bank, Operational Directive 4.00, Annex A (Oct. 1989).

Cf. Bowles / Kormos, note 7, p. 826-827; Tundermann, note 4, § 10.02 [1], quoting the World Bank's "Checklist on Community Involvement in Environmental Assessment".

11 Cf. Usubillaga Velásquez, note 1, p. 30-31; the Declaration of Stockholm is available at <http:// www.unep.org > (accessed 15.07.2009).

12

The mandate and objectives of UNEP emanate from United Nations General Assembly resolution 2997 (XXVII) of 15 December 1972 and subsequent amendments. 
also known as Earth Summit - held in June 1992 in Rio de Janeiro, Brazil. ${ }^{13}$ One of the most significant achievements of the conference was the Agenda 21, serving as an exhaustive road map for achieving sustainable development. ${ }^{14}$ Interestingly for this research, according to Principle 10 of the Rio Declaration, "Environmental issues are best handled with the participation of all concerned citizens, at the relevant level." According to the Declaration emphasis should be placed on three important issues: (1) access to information, (2) access to process, and (3) access to justice.

\section{Nicaraguan Legislation on Environmental Law}

As mentioned before, Nicaragua, in the 1990s and later, created remarkably elaborated environmental protection law. Landmarks in the process of legislation were the General Environmental Law of 1996 (Ley General del Medio Ambiente y los Recursos Naturales) ${ }^{16}$ and the Conservation Law of 2003 (Ley de Conservación, Fomento y Desarrollo Sostenible del Sector Forestal) ${ }^{17}$. Nicaragua also promulgated regulations and created regulatory agencies to implement these laws. The main responsibility for the implementation of environmental law lies in the hands of the central government of Nicaragua. However, also the regions and departments ${ }^{18}$ as well as the municipalities have competences concerning the protection of the environment. ${ }^{19}$

However, in Nicaragua, the responsibilities for the implementation of environmental law are divided among several entities and rather diffuse: The bigger part of the responsibility is divided among several Ministries. ${ }^{20}$ Within the Attorney General's Office (Procuraduría General de Justicia), the Attorney's Office of the Environment (Procuraduría para la Defensa del Ambiente y los Recursos Naturales) is created to observe compliance with environmental law. The latter's responsibility is the representation and the protection of the interests of the state and the society in the area, including the participation in litigation. $^{21}$ As far as Human Rights are affected by an environmental damage, the Ombudsman

Cf. Usubillaga Velásquez, note 1, p. 32-35.

The Agenda 21 is available at <http://www.unep.org> (accessed 15.07.2009).

The Declaration of Rio is available at <http://www.unep.org > (accessed 15.07.2009).

Ley No. 217 of 27.03.1996.

Ley No 462 of 2003.

Usubillaga Velásquez, note 1, p. 93

Article 7 Ley de Municipios, Leyes No. 40 and 261.

Usubillaga Velásquez, note 1, p. 89-93.

Articles 9 and 10 Ley 217 of 27.03.1996. 
system (Procuraduría de los Derechos Humanos) can be involved. ${ }^{22}$ Furthermore, legal protection can be found at the international level. ${ }^{23}$ For example, indigenous peoples from Nicaragua have brought claims before the Inter-American Court of Human Rights describing the devastation they have suffered due to resource extraction on their lands. The Court found a violation of the procedural right to judicial protection, as well as a violation of the substantive right to property. ${ }^{24}$

But as in most legal systems, so in Nicaraguan law, only those who have standing to sue have the right to judicial relief. Standing defines who has access to the courts and who has the possibility of counteracting unlawful conduct. ${ }^{25}$ As described before, standing to sue is vested only in those persons or groups who are affected in their individual rights. Individual rights can be provided by statutes or by the constitution. ${ }^{26}$ One might think that the Political Constitution of Nicaragua provides to every citizen a defendable right of environmental protection. The Constitution promises in Article 60 that the citizens of Nicaraguans have the right to live in a healthy environment; the preservation, conservation, and rescue of the environment and of the natural resources is the obligation of the State. However, Article 60 does not grant individual rights to individual persons. ${ }^{27}$ Article 60 is located in Chapter III of the Nicaraguan Constitution that provides a multitude of social rights. These social rights embody only programmatic provisions that do not create immediately applicable subjective rights.

The Supreme Court of Nicaragua (Corte Suprema de Justicia) - Constitutional Panel (Sala Constitucional) - stated this already for the right to employment mentioned in Article

Iván Escobar Fornos, Derecho Procesal Constitutucional: La Constitución y su defensa, p. 34-35 (Hispamer 1999); Jorge Flavio Escorcia, Derecho Administrativo, Primera Parte, p. 244 (Universidad Nacional Autónoma de Nicaragua 2002).

Escobar Fornos, note 6, p. 471; Hari M. Osofsky, Learning from Environmental Justice: A Model for International Environmental Rights, Stanford Environmental Law Journal 24 (2005), 71; Inara K.Scott, The Inter-American System of Human Rights: An Effective Means of Environmental Protection?, Virginia Environmental Law Journal 19 (2000), 197.

Case No. 79, Inter-Am. C.H.R., Ser. C (2001); see Osofsky, note 23, p. 98, 112.

Cf. on this general principle Escobar Fornos, note 23, p. 114; Richard J. Pierce, Jr. / Sidney A. Shapiro / Paul R. Verkuil, Administrative Law and Process, p. 139-140 (Foundation Press 4th ed. 2004). Mayton, Administrative Law 379-380 (West 2d ed. 2001); Pierce et al., note 25, p. 146-147.

\footnotetext{
However, more optimistic about the essence of Article 60 Usubillaga Velásquez, note 1, p. 70: "Si
} se tratara de un derecho fundamental, no habría ninguna excusa para limitar su garantía." 
57 and in Article $80 .^{28}$ According to the Supreme Court, the right to employment is to be considered as a mere orientation for the public powers, with a rather "ethical" character. From this understanding, the Supreme Court stated that this norm does not create an immediately applicable subjective right. ${ }^{29}$ In the same way a government cannot guarantee employment to the people, it cannot guarantee a healthy environment or the rescue of nature. One might think only of external influences like pollution coming from neighboring countries or of natural disasters that national governments can hardly counteract. Since the right to a clean environment in fact cannot be fulfilled by a government, the Supreme Court's understanding of a social right as a programmatic provision is to be transferred to Article 60s right to environmental protection.

However, Nicaraguan environmental law includes exceptions from the standing requirement. Interestingly, in Article 2 of the General Environmental Law it is stated that every citizen can initiate administrative or criminal proceedings against those who violate that law. In case of a violation, the Attorney's Office to the Environment will take part in the procedures to watch the compliance of environmental laws. ${ }^{30}$ Although the recognition of standing to sue for private parties on behalf of the public brought a radical change in legal theory, up to now the involvement of civil society in the judicial system has been rather poor.

The action provided by Article 2 of the Nicaraguan General Environmental Law, the citizen suit in the U.S. law, and the association action (Verbandsklage) in German law pursue the same goal. They are meant to ensure that private parties have the possibility to enforce the law on behalf of the public at large. ${ }^{31}$ In the U.S. and in Germany the legislature has relied increasingly on this form of law enforcement. Especially in environmental law, citizen suits and association actions are considered to be an effective tool to encourage

Sala Constitucional, 10.10.2000, 12:30 p.m., p. 1164, 1165, "Pues desde quienes lo consideran una mera orientación para los poderes públicos, de carácter más ético que jurídico o bien una norma programática que no crea un derecho subjetivo inmediatamente aplicable y tutelable, pero que sí prohíbe ciertas opciones al legislador, hasta quienes lo consideran como un derecho de crédito para el Estado", quoted in: Escobar Fornos, note 6, p. 382.

Cf. also Ampié Vílchez, note 6, p. 223; Martin Kellner, The Political Constitution of Nicaragua and its Supreme Court of Justice, Jahrbuch des Öffentlichen Rechts der Gegenwart 57 (2009) 695, 706.

Article 135 Ley 217 of 27.03.1996.

31 Cf. Bernard Schwartz, Administrative Law, p. 499 (Little, Brown \& Comp 3d ed. 1991); Michael Kloepfer, Umweltrecht, 2d ed. 1998, p. 522-523; Rainer Wahl / P. Schütz, § 42, Section 2 n. 235 , in: Friedrich Schoch / Eberhard Schmidt-Aßmann / Rainer Pietzner (eds). Verwaltungsgerichtsordnung, 2004. 
agencies to implement statutory provisions. ${ }^{32}$ As mentioned before, the reason for this development is that in environmental law with the protection of the nature the protection of a general benefit is in question, and in many cases an omission of implementation does not injure an individual who could claim statutory enactment. ${ }^{33}$ The U.S. Congress introduced this form of law enforcement quite early. In the 1960s and 1970s, Congress hoped to counteract the relatively weak political influence of private beneficiaries with the help of citizen suits. ${ }^{34}$ Similarly, but not before the 1990 s, association actions were introduced in the Federal Republic of Germany. First the German states created legal actions taken by associations, ${ }^{35}$ and later the federal legislature allowed this kind of litigation by an amendment to the Federal Nature Conservation Law (Bundesnaturschutzgesetz). ${ }^{36}$ However, in recent years, in both countries converse developments in the uses of this tool can be noted.

\section{Citizen Participation in the U.S.}

In the U.S., in the 1960s and 1970s, observers of regulatory law claimed that congressional purposes could be undermined by insufficient regulation and agency's hostility to statutory programs. ${ }^{37}$ Empirical literature suggested that agencies were sometimes subject to sustained political pressure from the regulated industries. ${ }^{38}$ As a result of a continuous exercise of power by well-organized private groups, statutory enactments could be defeated during implementation. ${ }^{39}$ Additionally to being the object of the external pressure, "clientele agencies" that generally are concerned with promoting the interests of a given sector of the economy were accused of being tendentious. The reason for this situation was found in the frequent interaction between the agency and the regulated industries, and in the exchange of personnel between both organizations. The result of these mechanisms was

Cf. on association actions in other fields of German law Wahl / Schütz, note 31, § 42, Section 2 n. 228 . Gellermann, note 2, Introduction to $§ 58$ BNatSchG n. 1.

Gesetz zur Neuregelung des Rechts des Naturschutzes und der Landschaftspflege und zur Anpassung anderer Rechtsvorschriften of 23.03.2002, Bundesgesetzblatt 2002, I, p. 1193. Law Journal 30 (1999), 471, 510-511; Fletcher, note 34, p. 251-252.

Cf. Marver H. Bernstein, Regulating Business by Independent Commission (Princeton University Press, 1955); Mancur Olson, The Logic of Collective Action: Public Goods and the Theory of Groups (Harvard University Press, 1971).

Jonathan H. Adler, Stand or Deliver: Citizen Suits, Standing, and Environmental Protection, Duke Environmental Law \& Policy Forum 12 (2001), 39, 44; Casdorph, note 37, p. 510-511. 
what is known as "agency capture." This is a situation of agencies being more responsive to a special interest group as opposed to Congress and the Presidency. ${ }^{40}$

Congress hoped to overcome administrative inactivity and to counteract the relatively weak political influence of private beneficiaries by activating private participation. To provide to citizens the right to challenge agency's conduct at the courts seemed to be an appropriate means to overcome administrative inactivity and agency capture. ${ }^{41}$ However, access to the courts was reserved for those parties who have standing to sue. ${ }^{42}$

Congress exercised its power to extend the group of people that have access to judicial review by creating citizen suits. ${ }^{43}$ These suits could be initiated by "concerned citizens," and were available against private defendants operating in violation of statute, and administrations failing to enforce the law as Congress required. ${ }^{44}$ Congress has considered citizen suit provisions to be an efficient policy instrument as well as a democratic, participatory tool that allows citizens to challenge environmental damage and pollution. ${ }^{45}$ An example of such a statute is provided by the Endangered Species Act such that "any person may commence a civil suit on his own behalf ... to enjoin any person, including the United States and any other governmental instrumentality or agency, ... who is alleged to be in violation of any provision of this chapter." sonal wrong, litigants in a citizen suit act as "private attorneys general" on behalf of the public at large. The power that citizen suit provisions transfer to private plaintiffs always made this tool suspicious. 48

After the legislature introduced citizen suit provisions in many statutes, the U.S. Supreme Court limited their scope significantly. The Supreme Court reduced the scope of

Cf. Andrew P. Morriss / Bruce Yandle / Andrew Dorchak, Choosing how to Regulate, Harvard Environmental Law Review 29 (2005), 179, 216-220; Pierce et al., note 25, p. 18-19.

41 Cf. Fletcher, note 34, p. 253-254.

42

Ann Woolhandler / Michael G. Collins, State Standing, Virginia Law Review 81 (1995), 387, FN. 2; cf. Fletcher, note 34, p. 229. Nancy C. Staudt, Modeling Standing, New York University Law Review 79 (2004), 612, 612 613.

Cass R. Sunstein, What's Standing after Lujan?, Michigan Law Review 91 (1992), 163, 192-193; Martin Kellner, Congressional Grants of Standing in Administrative Law and Judicial Review, Hamline Law Review 30 (2007), 315, 332-333. Adler, note 39, p. 43; Sunstein, note 44, p. 192-193. Endangered Species Act, 16 U.S.C., Section 1540(g) (2002). 
these provisions to cases, in which the claimant is injured in fact. ${ }^{49}$ With this reduction, the Court factually suspended citizen suit provisions. ${ }^{50}$ Mainly, this "shift to conservatism" is due to Justice Antonin Scalia's influential opinions, written since the beginning of the 1990 s. $^{52}$ Justice Scalia reluctance towards an extension of standing is a result of his understanding of separation of powers and of his interpretation of Article III of the U.S. Constitution. In the classical understanding of separation of powers, the judiciary's function is solely to protect individuals from violations of their rights. Thus, courts can check governmental conduct only when a plaintiff's rights were violated. ${ }^{53}$ Additionally, Article III, Section 2 states that "[t]he judicial Power shall extend to all Cases [and] to Controversies". Therefore, judges shall be limited to hearing specified circumstances and could get to exercise power only when other actors - public officials and private citizens - created justiciable circumstances and bring them to the courts. That means standing to sue exists only for parties who are injured in fact in their individual interests or rights. ${ }^{54}$ By using a narrow interpretation in order to restrain citizen suit provisions, the Supreme Court suspended these provisions and restricted broadly Congress' power to extend the scope of judicial review. 55

Bearing in mind the constitutional background, the Supreme Court barred in several decisions ideological plaintiffs that have no personal stake in litigation and thus have no standing to sue. For example, in Lujan v. Defenders of Wildlife ${ }^{56}$ plaintiffs relied on the suit provision of the Endangered Species Act. They alleged that the Department of the Interior had wrongfully determined that this Act did not apply to U.S.-supported projects in foreign nations. But the Court objected that the Defenders of Wildlife failed to allege sufficient imminence of injury because they had no concrete plan to travel to those places where the

Cf. Lujan v. Defenders of Wildlife, 504 U.S. 555 (1992); Steel Company v. Citizens for a Better Environment, 523 U.S. 83 (1998).

Pierce et al., note 25, p. 143; Kellner, note 44, p. 358.

51

Casdorph, note 37 , p. 503.

52 Lujan v. Defenders of Wildlife, 504 U.S. 555 (1992); Bennett v. Spear, 520 U.S. 154 (1997); Steel Company v. Citizens for a Better Environment, 523 U.S. 83 (1998); Friends of the Earth $v$. Laidlaw, 528 U.S. 167, 198 (Justice Scalia, dissenting) (2000).

Cf. Louis Fisher, American Constitutional Law 79-81 (Carolina Academic Press 4th ed. 2001); Antonin Scalia, The Doctrine of Standing as an Essential Element of the Separation of Powers, Suffolk University Law Review 17 (1983), 881, 894. Cf. Lujan v. Defenders of Wildlife, 504 U.S. 555 (1992); Steel Company v. Citizens for a Better Environment, 523 U.S. 83 (1998). 
endangered animals lived. In the Court's view, the plaintiffs were left in the position of a general grievance regarding the agency's alleged failure to properly implement the Endangered Species Act. This general grievance did not constitute standing. In the Court's words, Article III of the U.S. Constitution requires more than "a generally available grievance about government" and "claiming only harm to his and every citizen's interest in proper application of the Constitution and laws." A claimant "seeking relief that no more directly and tangibly benefits him than it does the public at large" is no appropriate party in the sense of Article III. ${ }^{57}$

\section{Citizen Participation in Germany}

In Germany, in the 1970s, public concern about environmental protection gradually increased. ${ }^{58}$ That stimulated the legislature to develop vivid activity in environmental affairs. It started several programs in order to protect the environment. In earlier times, the German legislature was only infrequently active on this field. ${ }^{59}$ This development took place on the federal and on the state level as well and reached its culmination federally in the creation of a new Federal Nature Conservation Law (Bundesnaturschutzgesetz) ${ }^{60}$ in 1976. However, in the following years, it turned out that the mere ambitious new statutes did little about the progressing devastation of nature. ${ }^{61}$ One reason for the poor success of legislation was the lack of implementation of environmental law. Reasons for the lack of implementation were found in the missing power of environmental interests and agencies' unwillingness to execute the law. ${ }^{62}$ Environmental interests were often unheard when there was nobody who could complain about a wrong or missing implementation of environ-

Id., p. 556.

Cf. Eckard Rehbinder / Hans-Gerwin Burgbacher / Rolf Knieper, Bürgerklage im Umweltrecht, 1972, p. 11; Alexander Schmidt / Michael Zschiesche / Marion Rosenbaum, Die naturschutzrechtliche Verbandsklage in Deutschland, 2004, p. 3

Cf. Werner Hoppe / Martin Beckmann / Petra Kauch, Umweltrecht, 2000, p. 49; Rehbinder et al., note 58, p. 11.

60 Gesetz über Naturschutz- und Landschaftspflege (Bundesnaturschutzgesetz) of 20.12.1976, Bundesgesetzblatt 1976, I, p. 3574, current version available at <http://bundesrecht.juris.de> (accessed 15.07.2009).

61

Johann Bizer / Thomas Ormond / Ulrike Riedel, Die Verbandsklage im Naturschutzrecht, 1990,

62 p. 17.

Hans-Joachim Koch, Die Verbandsklage im Umweltrecht, Neue Zeitschrift für Verwaltungsrecht 26 (2007), 369; Gertrude Lübbe-Wolff, Das Kooperationsprinzip im Umweltrecht - Rechtsgrundsatz oder Deckmantel des Vollzugsdefizits?, Natur und Recht 11 (1989), 295; Rehbinder et al., note 58 , p. 11. 
mental law. ${ }^{63}$ At German Administrative Courts it is the rule, that court only decide about cases if the claimant is injured in a subjective right. ${ }^{64}$ Therefore, generally spoken, plaintiffs who are not injured cannot proceed against agency's action or inaction.

In environmental law, when the implementation of general statutory programs is required, in many instances affected individuals are missing. ${ }^{66}$ In these situations, there is no possibility to demand the environmental protection from an agency at the courts. ${ }^{67}$ When German scholars looked for a remedy to this state of affairs, the citizen suit provisions of the U.S. law were regarded as a model. ${ }^{68}$ However, the German legislature did not want to rely on the actions of individuals as the citizen suit provisions do. Not "any person" was regarded an appropriate party to challenge an agency's decisions on behalf of the public. Only approved associations were granted the privilege of being the "attorney of environment" minimum of legitimation of the private party and to bundle a multiplicity of private interests. $^{70}$

Whereas the citizen suit provisions in the U.S. experienced a suspension by the judiciary, in Germany, the scope of association actions is still expanding. A new stimulus was contributed by the Aarhus Convention (Convention on Access to Information, Public Participation in Decision-making and Access to Justice in Environmental Matters). ${ }^{71}$ The

$\S 40$, Section 2 Rules of the Administrative Process (Verwaltungsgerichtsordnung). Cf. for more details on standing in German administrative law (Klagebefugnis) Thomas von Danwitz, Zur Umsetzung der Richtlinie 2003/35/EG und der sog. Aarhus-Konvention, Umwelt- und Technikrecht 93 (2007), 31, 34-35.

Ferdinand O. Kopp / Wolf-Rüdiger Schenke, Verwaltungsgerichtsordnung, § 42 n. 59, 14th ed. 2005.

Bizer et al., note 61, p. 28-29; Gellermann, note 2, Introduction to § 58 BNatSchG n. 1.

Cf. Erich Gassner, § 58 n. 2, in: Erich Gassner / Gabriele Bendomir-Kahlo / Annette SchmidtRäntsch / Jürgen Schmidt Räntsch (eds)., Bundesnaturschutzgesetz, 2d ed. 2003; Rehbinder et al., note 58, p. 57; Bizer et al., note 61, p. 50.

Cf. Robert Seelig / Benjamin Gründling, Die Verbandsklage im Umweltrecht, Neue Zeitschrift für Verwaltungsrecht 21 (2002), 1035. The phrase "attorney of the environment" ("Anwalt der Natur") used the Federal Administrative Court (Bundesverwaltungsgericht), Entscheidungen des Bundesverwaltungsgerichts 92 (1993), 258, 262; id., Neue Zeitschrift für Verwaltungsrecht 17 (1998), 279, 280.

70 Rehbinder et al., note 58, p. 151-153.

71 The Convention is available at <http://www.unece.org/env/pp/treatytext.htm> (accessed 15.07.2009). 
Aarhus Convention, drafted under the auspices of the United Nations Economic Commission for Europe (UNECE), aims to put the principle of the Declaration of Rio de Janeiro of 1992 into practice. ${ }^{72}$ The Convention recognizes that sustainable development can only be implemented if everyone is involved and, therefore, intends to expand the participation of citizens in order to enhance the efficiency and the acceptance of administrative procedures. ${ }^{73}$ However, the Aarhus Convention is regional in scope and covers only the European continent in the broadest sense, including the countries of Central Asia.

The Convention was signed by the member states in 1998 in the Danish city of Aarhus. It entered into force on October 30, 2001 and is still in the process of ratification. It contains three broad themes or "pillars": (1) access to information, (2) public participation and (3) access to justice. In order to make violation of participation rules provided by the Convention judiciable, the Aarhus Convention promotes objective forms of judicial review and - especially for this purpose - association actions. ${ }^{74}$ The intention of the Convention is to establish minimum standards to be achieved but does not prevent its parties from measures which go further (Article 3, Section 5). ${ }^{75}$ However, the Convention has a slightly different objective than the conventional association action in German law. Whereas the latter pursues the enforcement of environmental law, the third pillar of the Convention intends to support the citizen participation in order to enhance the efficiency and the acceptance of administrative procedures. 76

In December 2006, the German legislature drew consequences from the Aahrhus Convention with introducing the Environment Action Act (Umwelt-Rechtsbehelfsgesetz). ${ }^{77}$ This statute provides a new kind of legal action to approved associations. The new action is the result of a rather reluctant attitude of the legislature towards an extension of citizen participation in the judicial process: The statute extends the scope of association actions to all violations of norms that are meant to serve the protection of nature. However, at the same time, the statute restricts the scope of the new action when it requires that the norms in question must create subjective rights to an individual person. ${ }^{78}$ With this restriction, the German legislature intended to maintain the traditional concept that courts only decide

Cf. the Preamble to the Aarhus Convention, and Thomas von Danwitz, Aarhus-Konvention: Umweltinformation, Öffentlichkeitsbeteiligung, Zugang zu den Gerichten, Neue Zeitschrift für Verwaltungsrecht 23 (2004), 272, 273.

Cf. the Preamble to the Aarhus Convention.

Sabine Schlacke, Rechtsschutz durch Verbandsklage, Natur und Recht 26 (2004), 629, 633.

Article 3, Section 5 Aarhus Convention.

76

77

Cf. the Preamble to the Aarhus Convention.

78

Umwelt-Rechtsbehelfsgesetz of 06.12.2006, Bundesgesetzblatt 2006, I, p. 2816.

$\S 2$ paragraph 5 Environment Action Act (Umwelt-Rechtsbehelfsgesetz). 
about cases if the claimants are injured in their subjective rights. ${ }^{79}$ This gives to the association action of the Environment Action Act a different feature than the association action of the German Federal Nature Conservation Law have. While the Nature Conversation Law makes the association an "attorney of the environment" the Environment Action Act gives associations the function to defend subjective rights of affected individuals. ${ }^{80}$ Since the extension of the scope of association action by the Environment Action Act was rather minor, there is a vivid discussion in Germany, if the amendment fulfilled all requirements provided by international law. 81

\section{Summary}

It can be noted that the idea of citizen participation in environmental protection law exists throughout the world. ${ }^{82}$ Interestingly, the histories of statutes providing standing to sue to individual persons or associations in environmental law are not isolated, but, on the contrary, related and interwoven in many respects.

What can be learnt from the experiences with citizen participation in the judicial process in the U.S. and in Germany? It is remarkable that in the U.S. as well as in Germany concerns about the quality of the judicial processes at the court existed and had much influence on legislative development. In the U.S., the discussion about the requirement of Article III and the requirement that a case or controversy must be in dispute is one expression of this concern. ${ }^{83}$ The worry was that plaintiffs who have no personal stake in the outcome of the controversy were presumed not to pursue their claims as vigorously as injured complainants do. Without suffering a personal injury, the litigants were expected merely to seek to enforce laws on behalf of the public-at-large what could lead to ineffective lawyering and negative judicial outcomes. ${ }^{84}$ In Germany, the solution to that problem was the rather reluctant use of citizen participation. From the beginning, only approved associations were admitted to the courts. These groups were presumed to guarantee a better

Von Danwitz, note 64, p. 57; Kellner, note 2, p. 156-157. des Rechtsschutzes in Umweltangelegenheiten, Zeitschrift für Umweltrecht 21 (2009), 115-122; Schlacke, note 81, p. 13-15; Wolfgang Schrödter, Aktuelle Entscheidungen zum Umwelt-Rechtsbehelfsgesetz, Neue Zeitschrift für Verwaltunsgrecht 28 (2009), 157-160; von Danwitz, note 64, p. 56-57. angemessenen Gestaltung von Verwaltungsverfahren, Natur und Recht 27 (2005), 71-79. 
litigation than individual persons at the court could. ${ }^{85}$ However, although both legal systems use different approaches to citizen participation, with respect to the group of stimulated citizens, the practical results did not differ very much. Whereas in Germany the statutory provisions only allow associations access to the courts, also in the U.S. only few environmental activist organizations filed the majority of citizen suits. The reason for this development in the U.S. can be found in the high cost of litigation that hardly allows an individual citizen to start litigation. ${ }^{86}$

For the Nicaraguan environmental law, a broader involvement of civil society in the environmental protection is clearly desirable. Article 2 of the General Environmental Law provides access to the courts to every citizen. This means, Nicaragua possesses a broad approach to citizen participation that is comparable to the original citizen suit of the U.S. law. Since the practical use of this provision is rather limited, it appears not to be promising to think about a reduction of this provision to associations, as it is know in German law. Nevertheless, to raise the practical meaning of Article 2 it seems to be most promising to focus on a broader involvement of NGOs. Such organizations can be expected to have a clear focus on environmental protection and to have the expertise that is necessary to guarantee a certain quality of to litigation. However, the society of Nicaragua is not so pluralist as the ones of the U.S. and Germany and not many national interest groups have the power and assertiveness that is necessary to guarantee a forward-pressing legal process in the courts. Still, much is to be done to give citizen participation a success story in Nicaragua.

However, citizen participation promises to be fruitful. Fruits are not only the direct results of the concrete litigation with citizen involvements and the raise in democratic legitimation of governmental decisions. ${ }^{87}$ On a broader view, citizen participation could also give civil society a better awareness of the necessity to protect nature. Already the founders of the Aarhus Convention recognized in the Preamble to the Convention that the extension of citizen participation in environmental matters can promote environmental education to further the understanding of the environment and sustainable development and encourage widespread public awareness of decisions affecting the environment and sustainable development. ${ }^{88}$ This concept also appears to be promising for environmental protection in Nicaragua.

Rehbinder et al., note 58, p. 151-153.

Cf. Adler, note 39, p. 48; Juliane Kokott / Leo-Felix Lee, Die Verbandsklage im deutschen und US-amerikanischen Umweltrecht, Umwelt- und Technikrecht 45 (1998), 215, 237.

Pünder, note 82, p. 73-74; see also Obregón Ortega, note 3, p. 34.

Paragraph 14 of the Preamble to the Aarhus Convention. 